\title{
THE METALLIC-COLORED HALICTINE BEES OF THE PHILIPPINE ISLANDS
}

\author{
By T. D. A. Cockerell \\ Of the University of Colorado
}

The subfamily Halictinæ, numerously represented in almost every part of the world, contains groups of species in which the surface of the body is black, brown, or yellowish, and others in which portions, at least, are metallic green or blue. The large genus Halictus, as generally understood, contains both metallic and nonmetallic species. In the Holarctic Region, Robertson has separated the metallic species as genera Chloralictus Robertson and Seladonia Robertson. He also recognizes, in North America, genera Dialictus Robertson (with only two submarginal cells) and Paralictus Robertson. How many such genera should be segregated from the old Halictus, it is hard to decide; and certainly the Robertsonian groups are less distinct than the genera commonly recognized among bees. The French entomologist Vachal went as far from current usage on the other side and not only refused to accept Robertson's genera, but threw into Halictus such genera as Augochlora and Agapostemon, almost universally considered distinct. The genus Nomioides Schenck, placed as a subgenus of Halictus by Dalla Torre, must be considered a distinct genus. Its members are small, usually with conspicuous yellow markings, almost perfectly imitating the American panurgine genus Perdita. Yet the venation is like that of Halictus, except that the marginal cell is narrowly truncate at the end. These bees are so unlike the species of Halictus that Cameron described several of them in Ceratina. Thus my Nomioides comberi from India must be called $N$. punjabensis (Cam.) ; for Meade-Waldo, on examining Cameron's types, found that his Ceratina punjabensis, published about four years earlier, was in fact my insect. It also appears that Ceratina cerea Nurse is to be called Nomioides pulchella Schenck or, according to the synonymy indicated by Alfken, N. parvula (Fabricius).

Mesothorax green

Genus NOMIOIDES Schenck

Mesothorax steel blue, highly polished.

1. Larger; abdomen with four entire yellow bands; mesothorax duller. dapitanellus Cockerell.

Smaller; abdomen with four (varying to two) lateral yellow marks, representing two widely interrupted bands; mesothorax more sshining. valdezi Cockerell. 
2. Larger (length, about 6 millimeters); abdomen black, without light markings. melanogaster Cockerell.

Smaller; abdomen marked with yellow. valdezi Cockerell.

Nomioides dapitanellus Cockerell.

Nomioides dapitanellus COCKERELL, Entomologist 48 (1915) 107.

Mindana0, Dapitan (Baker 3161).

Nomioides valdezi Cockerell.

Nomioides valdezi Cockerell, Ann. \& Mag. Nat. Hist. VIII 16 (1915) 487.

Mindana0, Cagayan (Baker 3670), type locality. Also PalaWAN, Puerto Princesa (Baker 8065). In the Palawan males the mesothorax is usually steel blue, as in the type, but occasionally it is shining green. There are two females from Palawan. They are about 5.2 millimeters long; mesothorax green; scutellum with two large yellow spots; postscutellum with a yellow bar; abdomen with large oblique cuneiform yellow marks at sides of second and third segments.

Nomioides melanogaster Cockerell.

Nomioides melanogaster Cockerell, Ann. \& Mag. Nat. Hist. VIII 16 (1915) 487.

MindanaO, Dapitan (Baker 3162).

Genus HALICTUS Latreille

Females 1.

Males 4.

1. Mesothorax shining green; abdomen more or less purplish, green at base subpurpureus sp. nov. Mesothorax dullish or granular or abdomen not purplish................. 2.

2. Abdomen bright green. 3. Abdomen bluish green to olive green, but knees red; scape red at base. adonidiæ sp. nov. Abdomen dark, at most slightly greenish. pervarians sp. nov.

3. All the tibiæ red; scape red at base Tibiæ black; scape all black.

4. Abdomen black, slender. Abdomen metallic, not slender. taclobanensis Cockerell. imuganensis sp. nov. pervarians sp. nov.

5. Abdomen blue-green; legs mainly dark. cyanescens sp. nov. Abdomen yellowish green; tibiæ and tarsi clear ferruginous; base of scape ferruginous. taclobanensis Cockerell.

Halictus taclobanensis Cockerell.

Halictus taclobanensis CockererL, Ann. \& Mag. Nat. Hist. VIII 16 (1915) 488.

LEYTE, Tacloban (Baker 3672), type locality. LUZON, Mount Maquiling (Baker), female. Mrndanao, Davao (Baker 8067), 
male; Cagayan (Baker), male. The male has the form of a female, as in certain Australian species, and the only conspicuous differences are in the longer antennæ and the caudal end of the abdomen.

\section{Halictus subpurpureus sp. nov.}

Female.-Length, about 6.5 millimeters; head very dark greenish, almost black; mandibles rufous at apex; clypeus feebly and sparsely punctured; supraclypeal area purplish; front with a sericeous luster; antennæ entirely black; mesothorax yellowish green, shining but not polished, without evident punctures; scutellum and hind margin of mesothorax glaucous green; area of metathorax large, with a very fine irregular reticulation; posterior truncation not sharply margined at sides; tegulæ dark brown; wings dusky, stigma black; first recurrent nervure meeting second transverse cubital; third submarginal cell narrow, quadrate, shaped nearly like the second; legs black; abdomen dorsally shining without bands and without evident punctures, the general color black, but the base greenish and the middle segments conspicuously suffused with purple; venter with large tufts of pale ocherous hair at the sides of the segments.

LuzoN, Baguio, Benguet (Baker). Related to $H$. pervarians, but larger, with mesothorax more shining, and abdomen suffused with purple.

Halictus pervarians sp. nov.

Female.-Length, about 5.5 millimeters; head rather small, glaucous green; antennæ black; mesothorax and scutellum yellowish green, shining but not polished, without evident punctures; mesothorax with a median longitudinal depression; area of metathorax appearing dull and granular under a lens, the broadly rounded margin shining; tegulæ pale brown, dark at base; pleura bluish green; wings faintly dusky; stigma black; first recurrent nervure meeting second transverse cubital; third submarginal cell short; outer nervures of third submarginal and outer discoidal cells weakened; legs black; abdomen without bands, black with a greenish or brassy tint. Ventral segments of abdomen with lateral ocherous tufts as in $H$. subpurpureus.

Variety $a$. Front peacock green and supraclypeal area purple.

Variety $b$. Length, about 5 millimeters; tegulæ pale testaceous; tarsi ferruginous; stigma brown.

Variety c. Flagellum reddish beneath; mesothorax and scutellum very dark green; area of metathorax dark bluish. Stigma black as in the typical form. 
Male.-Antennæ very long, black; face green; abdomen slender, black; tarsi, and anterior tibiæ in front, ferruginous. A male from Mount Banahao is considerably larger than one from Mount Maquiling.

LuzoN, Mount Maquiling (Baker), type and varieties $a$ and $b$; Imugan (Baker), variety $c$; Mount Banahao (Baker), male. Very variable, but apparently all one species. I have nine specimens before me.

Halictus imuganensis sp. nov.

Female.-Length, about 7 millimeters; bright golden green, the clypeus, mesothorax, and scutellum variably suffused with coppery red, or entirely green, or the clypeus peacock green; mandibles obscure reddish; face, front, mesothorax, and scutellum with a roughened granular surface; antennæ black; area of metathorax shining, with strong, irregular plicæ, forming a coarse irregular network; posterior truncation sharply defined at sides; thorax above with thin ocherous hair; tegulæ rufopiceous; wings very faintly dusky; stigma black; second submarginal cell large and broad, receiving first recurrent nervure at its apical corner; outer transverse cubital and recurrent nervures weakened; legs black; abdomen shining, without bands; a well-developed ventral scopa.

LUzoN, Imugan (Baker), type locality. Mount Banahao (Baker): Baguio, Benguet (Baker). Five specimens are before me. Allied to $H$. taclobanensis.

Halictus adonidiæ sp. nov.

Female.-Length, about 6.5 millimeters; shining green, with dark tarsi, tegulæ rufotestaceous, and basal half of scape red. Closely allied to $H$. imuganensis Cockerell, differing in the color of scape, the bluish green (not brassy green) abdomen, the broader head, the scutellum and posterior half of mesothorax brilliantly shining, and the paler (brownish) stigma.

LUZoN, Manila, Malate (R. C. McGregor), October 27, 1918, at flowers of Adonidia merrillii Beccari.

Halictus cyanescens sp. nov.

Male.-Length, a little over 5 millimeters; head, thorax, and abdomen blue-green; face and front, including clypeus, dull and granular; antennæ black; mesothorax granular; area of metathorax irregularly reticulate; posterior truncation sharply defined at sides; tegulæ testaceous; wings very faintly dusky, 


\section{$2 \mathrm{BHL}$ Biodiversity Heritage Library}

Cockerell, Theodore D. A. 1919. "The metallic-coloured Halictine bees of the Philippine Islands." The Philippine journal of science 15, 9-13. https://doi.org/10.5962/bhl.part.11763.

View This Item Online: https://www.biodiversitylibrary.org/item/1125

DOI: https://doi.org/10.5962/bhl.part.11763

Permalink: https://www.biodiversitylibrary.org/partpdf/11763

\section{Holding Institution}

Missouri Botanical Garden, Peter H. Raven Library

\section{Sponsored by}

Missouri Botanical Garden

\section{Copyright \& Reuse}

Copyright Status: Public domain. The BHL considers that this work is no longer under copyright protection.

This document was created from content at the Biodiversity Heritage Library, the world's largest open access digital library for biodiversity literature and archives. Visit BHL at https://www.biodiversitylibrary.org. 